D. O. Yevtushenko,

I. A. Taraban, D. V. Minukhin, O. M. Shevchenko

State Institution «Zaitsev V. T. Institute of General and Urgent Surgery of National Academy of Medical Sciences of Ukraine», Kharkiv

(C) team of authors

\section{CURRENT QUESTIONS OF DIAGNOSIS AND TREATMENT OF PATIENTS WITH PERITONEAL ADHESIVE DISEASE}

Annotation. The article provides a review of the literature on the topic of peritoneal adhesive disease and its complications. Patients with peritoneal adhesive disease require a detailed examination in order to determine the treatment algorithm for this category of patients. Traditional surgical interventions used in intestinal obstruction and do not give the desired effect, inevitably causing a recurrence of adhesions. To diagnose the cause of obscure abdominal pain in recent years have increasingly used the laparoscopic approach. Operative laparoscopy is widely used to treat patients with abdominal adhesions disease.

Key words: peritoneal adhesive disease, acute intestinal obstruction, laparoscopy.
Abdominal adhesive disease - a serious illness, often occurring in young and working age. In typical clinical situations adhesive disease diagnosis does not present any difficulties, and the choice of method of treatment depends on the presence or absence of intestinal obstruction [1, 2].

In connection with the widespread introduction into surgical practice surgeries on abdominal organs, the relevance problem peritoneal adhesive disease is growing steadily.

Peritoneal adhesive disease is one of the common diseases in the world. Recently spread spectrum and volume of surgical interventions a steady rise in the incidence of postoperativedevelopment of peritoneal adhesive disease.

Despite intensive development of minimally invasive technologies that have significantly reduced surgical trauma, the number of the nearest and long-term complications caused by adhesion process is not reduced [3, 4].

Common operations that cause abdominal adhesive disease - operations on the descending and rectum (25\%), followed by appendectomy $(15 \%)$, gynecologic surgery $(14 \%)$ and total colectomy $(9 \%)$. In general, $76 \%$ of patients developed adhesions after operations performed below the transverse colon, $14 \%$ - above the transverse colon, and in $14 \%$ of cases the cause was peritonitis adhesive obstruction. About $1 \%$ of all admissions to hospitals and surgical laparotomy $3 \%$ due to adhesive disease of the abdomen and its complications $[5,6]$.

Frequency of adhesion formation varies from 67 to $93 \%$ after surgical abdominal operations and is nearly $97 \%$ after open gynecologic surgery. In modern abdominal surgery problem of postoperative abdominal adhesions not lost its relevance $[7,8]$.

Acute adhesive intestinal obstruction distinguish the severity and rapid development of the pathophysiological changes in the forms of strangulation, a variety of clinical manifestations and related difficulties in the diagnosis, tactical and technical complexity of the surgical treatment and prevention. Therefore, postoperative mortality in acute adhesive intestinal obstruction is kept at $15 \%$ capacity for work is restored only $40-50 \%$ of patients, and after conservative treatment - at $30-35 \%[9,10]$.

Surgical complications and diseases caused by adhesions may occur already in the immediate postoperative period. According to the summary data, the frequency of early adhesive intestinal obstruction varies between 12-27\% of all types of ileus. In pediatric practice, $8 \%$ of newborns who underwent intervention for abdominal organs, subsequently subjected to laparotomy for acute adhesive intestinal obstruction [11, 12].

Today, there are increasing work, noted the negative impact of adhesions in the pelvic area on the reproductive function of young women: $55 \%$ of patients the cause of infertility steel spikes in the fallopian tubes and ovaries, formed as a result of chronic pelvic processes.

Hospital stay after adhesiolysis performed laparotomy access in urgent procedure averages 20 days. Mortality reaches 7,0-18,0 \%, and at an early form of postoperative adhesive obstruction $19,5-50,0 \%$. With each subsequent attack of acute adhesive intestinal obstruction ileus recurrence risk increases with increasing $[12,13]$.

The rapid growth of advanced technologies in minimally invasive surgery, biology, chemistry, pharmacology and other paramedical fields of science and technology make it possible to put into practice new ways and means of prevention, diagnosis and treatment of adhesive disease. Pathogenetic sound direction in the prevention and treatment AADP is the use of various means of preventing 
adhesion of convergence and injured peritoneal surfaces.

Researchers from different countries appealed to the diagnosis and treatment of adhesive disease of the peritoneum using antiadhesive barrier means. The results of their work are contradictory, possibilities of the methods are assessed differently, many issues require further research and discussion. However, most authors note promising application antiadhesive barrier means, laparoscopic and traditional interventions in patients undergoing surgery for abdominal organs $[14,15]$.

At $11.6-38 \%$ of previously operated patients no signs of intestinal obstruction and the only clinical manifestation of the disease are persistent $a b-$ dominal pain. This group of patients are frequent diagnostic errors leading to unnecessary surgical interventions. Patients with abdominal adhesions often long, unsuccessfully treated without a specific diagnosis. Thus, as a rule, the diagnosis appears neurotic syndrome. Report this tactic due to the difficulty of establishing the true cause of pain [16].

Leading role in the diagnosis of peritoneal adhesive disease and X-ray methods of investigation of the gastrointestinal tract. Previously developed technique of X-ray of the stomach, followed by passage of barium and follow-up of his evacuation does not always give an idea about the topic of the process, especially when there vistsero parietal adhesions. Using similar methodology to the background pneumoperitoneum enhanced its diagnostic significance. Further improvement of the method of contrast study was retrograde filling of additional colon double contrast background for the detection of colon pathology. These methods have one very significant drawback - a large radial load and invasiveness studies at low specificity and sensitivity $[17,18]$.

Ultrasonography abdomencavity, widespread in recent years, opening up new possibilities in the diagnosis of peritoneal adhesive disease, especially in the development of acute adhesive intestinal obstruction. However, ultrasound helps to choose the zone entrytroacars into the abdominal cavity, free of vistseroparietaladhesions [19, 20].

The role of laparoscopy in the diagnosis of peritoneal adhesive disease is currently not fully understood. According to some authors, the presence of adhesions is a contraindication for laparoscopy and the risk of its use when other methods unjustified. With the advent of new technologies in endoscopic surgery and the development of safe methods of laparoscopic approach in terms of relax- ation, as well as with the use of ultrasound to visualize the possibilities of the method vistseroparietal adhesions increased significantly decreased and the number of complications [21, 22].

Development and outcome after surgery reparation paramount depends on the local reaction of inflammatory cells, the state of local immunity, which controls the differentiation of progenitor cells into fibroblasts and regulate their activity. Laws of dysregulation of the immune system in the formation of adhesions remain virtually unexplored.

Lately pathogenetic search methods for prevention and impact on the adhesion process is conducted among drugs acting on immunobiological reactivity of the organism. Set of preventive measures directed only to the activation of immune and cellular elementsproliferation by affecting the local inflammation.

Method laparoscopy was first used to treat the adhesive disease and its complications with high efficiency (53 to $80 \%$ ) in pediatric surgery. But remains undeveloped algorithm treatment of this disease, as conservative therapy provides only a temporary effect, and in $52.9 \%$ of patients he absent. Traditional surgical interventions used in intestinal obstruction and do not give the desired effect, inevitably causing a recurrence of adhesions. To diagnose the cause of obscure abdominal pain in recent years have increasingly used the laparoscopic approach. Operative laparoscopy is widely used to treat patients with abdominal adhesions disease [23, 24].

Wide-ranging discussion on the diagnosis, surgical treatment of adhesive disease abdomen indicates sustained urgency of this problem. Heterogeneity of symptoms, diagnostic difficulties and ambiguity of interpretation of the results obtained, as well as the inadequacy of existing differential criteria cause difficulty in choosing a rational method of treating a disease. It remains unclear place miniinvasiveinterventions in the treatment of painful forms of abdominal adhesive disease.

\section{Conclusion}

Patients with peritoneal adhesive disease require a detailed examination in order to determine the treatment algorithm for this category of patients. Traditional surgical interventions used in intestinal obstruction and do not give the desired effect, inevitably causing a recurrence of adhesions. To diagnose the cause of obscure abdominal pain in recent years have increasingly used the laparoscopi capproach. Laparoscopy is widely used to diagnosis and treatment patients with abdominaladhesions disease. 


\section{ПЕРЕЛІК ПОСИЛАНЬ:}

1. Курбонов КМ, Шарипов ХЮ, Абдулмачидзода А. Современные технологии в диагностике и лечении спаечной непроходимости тонкого кишечника. Харківська хірургічна школа.2009;4:239-41.

2. Stommel MW, Ten Broek RP, Strik C, Slooter GD, Verhoef C, Grunhagen DJ. Multicenter observational study of adhesion formation after open-and laparoscopic surgery for colorectal cancer. Ann Surg. 2018; 267(4):743-8.

3. Tabibian N, Swehli E, Boyd A, Umbreen A, Tabibian JH. Abdominal adhesions: A practical review of an often overlooked entity. Ann Med Surg (Lond) 2017;15: 9-13. DOI: 10.1016/j. amsu.2017.01.021

4. Reijnen MM, Bleichrodt RP, van Goor H. Pathophysiology of intra-abdominal adhesion and abscess formation, and the effect of hyaluronan. Br. J. Surg. 2013;90(5):533-41.

5. Vrijland WW, Bonthuis F, Steyerberg EW, et al. Peritoneal adhesions to prosthetic materials: choice of mesh for incisional hernia repair. Surg. Endosc. 2010;14(10):960-3.

6. Schnbriger B, Barmparas G, Branco BC, et al. Prevention of postoperative peritoneal adhesions: a review of the literature. Am. J. Surg. 2011;201(1):111-21.

7. Мендель НА. Профилактика спайкообразования и рецидивов острой непроходимости кишечника. Доказательные исследования. Хірургія України. 2012;3:85-91.

8. Мішалов ВГ, Бик ПЛ, Лещишин IM, Голінко ВМ. Застосування протизлукового гелю при резекції ділянки кишечнику на тлі злукового процесу одночасно з пластикою передньої черевної стінки променевої сіткою в експерименті. Хірургія України. 2014;1:43-51.

9. Yi X, Lin J, Zhou Q, Huang R, Chai Z. The TXA2R rs1131882, P2Y1 rs1371097 and GPIIIa rs2317676 threeloci interactions may increase the risk of carotid stenosis in patients with ischemic stroke. BMC Neurology 2019; 19(1):2-5.

10. Фелештинський ЯП, Яриновська ОВ. Профілактика спайкової хвороби при хірургічному лікуванні післяопераційних вентральних гриж. Хірургія України. 2011;3:116-7.

11. Bencini L, Sanchez LJ, Scatizzi M, et al. Laparoscopic treatment of ventral hernias: prospective evaluation. Surg Laparosc Endosc Percutan Tech. 2013;13(1):16-9.
12. Boys F. The prophylaxis of peritoneal adhesions. Br. J. Surg. 2012;89(1):50 -6.

13. Beyene RT, Kavalukas SL, Barbul A. Intra-abdominal adhesions: anatomy, physiology, pathophysiology, and treatment. Curr. Probl. Surg. 2015;52 (7):271-319.

14. Van Steensel S, van den Hil LCL, Schreinemacher MHF, ten Broek RPG, van Goor H, Bouvy ND. Adhesion awareness in 2016: An update of the national survey of surgeons. PLOS ONE 2018;13(8):1-3.

15. Bilsel Y, Abci I. The search for ideal hernia repair; mesh materials and types. Int. J. Surg. 2012;10(6):317-21, available at: https:// doi.org/10.1016/j.ijsu.2012.05.002

16. Dismore RC, Calton WCJr, Harvey SB, Blaney MW. Prevention of adhesions to polypropylene mesh in a traumatized bowel model. J. Am Coll. Surg. 2010;191:131-6.

17. Dwivedi AJ, Kuwajerwala NK, Silva YJ, Tennenberg SD. Effects of surgical gloves on postoperative peritoneal adhesions and cytokine expression in a rat model. Am. J. Surg.2014;188(5):491-4.

18. Felemovicius I, Bonsack ME, Hagerman G, Delaney JP. Prevention of adhesions to polypropylene mesh. J. Am. Coll. Surg. 2014;198:543-8.

19. Flatas E, Gunal O, Alatas O, Colak O. Octreotide prevents postoperative adhesion formation by suppressing peritoneal myeloperoxidase activity. Hepatogastroenterology. 2010;47(34):1934-6.

20. Kramer K, Senninger N, Herbst H, Probst W. Effective prevention of adhesions with hyaluronate. Arch Surg. 2012;137(3):278-82.

21. Masata J, Marta A, Poislowa M, et al. A comparison of the incidence of early postoperative infections between patients using synthetic mesh and those undergoing traditional pelvic reconstructive surgical procedures. Prague Med. Rep. 2013;114:81-91.

22. Mathes SJ, Steinwald PM, Foster RD, et al. Complex abdominal wall reconstruction: a comparison of flap and mesh closure. Ann Surg. 2010;232(4):586-96.

23. Ouaissi M, Gaujoux S, Veyrie N, Deneve E, Brigand C, Castel B, et al. Post-operative adhesions after digestive surgery: their incidence and prevention: review of the literature. Journal of Visceral Surgery. 2012;149:104-14.

24. Ten Broek RP, Strik C, Issa Y, Bleichrodt RP, van Goor H. Adhesiolysis-related morbidity in abdominal surgery. Ann Surg. 2013;258:98-106. 
АКТУАЛЬНІ ПИТАННЯ ДІАГНОСТИКИ ТА ЛІКУВАННЯ ХВОРИХ СПАЙКОВОЮ ХВОРОБОЮ ОЧЕРЕВИНИ

\section{Д. О. Свтуиенко, I. А. Тарабан, Д. В. Мінухін, О. М. Шевченко}

Реферат. Bcmyn. У статті подано огляд літератури на тему спайкової хвороби очеревини та її ускладнень.

Мета дослідження. Вивчення особливостей діагностики та лікування хворих зі спайковою хворобою очеревини та i ускладненнями.

Результати та обговорення. Пацієнти з спайковою хворобою очеревини вимагають детального обстеження 3 метою визначення алгоритму лікування цієї категорії пацієнтів. Традиційні хірургічні втручання застосовуються при кишковій непрохідності і не дають бажаного ефекту, неминуче викликаючи рецидив спайок.

Висновки. Для діагностики причини незрозумілих болів у животі в останні роки все частіше застосовують лапароскопічний підхід. Оперативна лапароскопія широко застосовується для лікування пацієнтів із захворюваннями спайок живота.

Ключові слова: спайкова хвороба очеревини, гостра кишкова непрохідність, лапароскопія.

Реферат. Введение. В статье представлен обзор литературы по теме спаечной болезни брюшины и ее осложнений.

Цель исследования. Изучение особенностей диагностики и АКТУАЛЬНЫЕ ВОПРОСЫ ДИАГНОСТИКИ И ЛЕЧЕНИЯ БОЛЬНЫХ СО СПАЕЧНОЙ БОЛЕЗНЬЮ БРЮШИНЫ
Д. А. Евтушенко,
И. А. Тарабан,
Д. В. Минухин,
А. Н. Шевченко лечения больных со спаечной болезнью брюшины и ее осложнениями.

Результаты и обсуждение. Пациенты с спаечной болезнью брюшины требуют детального обследования с целью определения алгоритма лечения этой категории пациентов. Традиционные хирургические вмешательства применяются при кишечной непроходимости и не дают желаемого эффекта, неизбежно вызывая рецидив спаек.

Bblводы. Для диагностики причины непонятных болей в животе в последние годы все чаще применяют лапароскопический подход. Оперативная лапароскопия широко применяется для лечения пациентов с заболеваниями спаек живота.

Ключевые слова: спаечная болезнь брюшины, острая кишечная непроходимость, лапароскопия. 